\title{
Improving Students' Self-directed Learning Outcomes on Mechanics Subject by Using E-Learning
}

\author{
Vina Serevina \\ State University of Jakarta, Jakarta, Indonesia \\ vina.serevina77@gmail.com
}

Received date: 5 October 2017; Accepted date: 28 January 2018; Published date: 13 Mars 2018

Academic Editor: Mohd Noah A. Rahman

Copyright (C) 2018. Vina Serevina . Distributed under Creative Commons CC-BY 4.0

\begin{abstract}
This study aims to improve learners' self-learning outcomes on mechanics subject using ELearning. The research method used was Miles and Huberman action research. The objects in this study were amounted to 31 students in the physics education program of State University of Jakarta. The research instruments used multiple choice questions and selfstudy learner questionnaire. The result of this research showed the effectiveness of Elearning on mechanics subject were obtained $\mathrm{N}$-gain equal to score 0,818 , so it was in very high category and there were increasing score of students' self-directed learning outcomes. In addition, the results of self-directed learning questionnaires were showed by aspect of the initiative with score 85\%, own effort aspect with score $88 \%$ and aspect of responsibility with score $97 \%$. The result of this study showed the improvement of students' self-directed learning outcomes on mechanics subject using E-learning.
\end{abstract}

Keywords: Students' Self-directed learning, learning outcomes, E-Learning.

\section{Introduction}

Technology development in globalization era is growing so fast. All sectors, including education, were demanded to be integrated with technology in order to produce competitive human resources (Kompas, 2012). Meanwhile, the development of information and communication technology in education has triggered a shift from face to face conventional learning to e-learning which can be accessed from any computers with no limitations. Along with the effects of globalization, education will be more open and two way, diverse, multi discipliner and related to competitive productivity (Kompas, 2014). Learning outcomes are the abilities of the students after they received a learning experience (Serevina, 2017).

In Antara News.com with the topic Indonesia $\mathrm{X}$ and UNPAD release free online course explained that Indonesia $X$ with State University of Padjadjaran (UNPAD) provide Massive Open Online Courses (MOOC) which gives free online courses

Cite this Article as: Vina Serevina (2018)," Improving Students' Self-directed Learning Outcomes on Mechanics Subject by Using E-Learning ", Journal of e-Learning and Higher Education, Vol. 2018 (2018), Article ID 187467, DOI: 10.5171/2018.187467 
access for everyone in all over Indonesia. Free online courses in indonesiax.co.id aims to democratize education in Indonesia so that everyone, everywhere in Indonesia can be attended (Antara News, 2016).

Previous research by Maha Bali (Maha Bali, 2015) stated that cMOOCs gives the opportunity to its participant to create a good collaboration which can help them to practice and develop skill in digital era.

cM00Cs can survive because of participant transformation to build connection between participants. Whereas, this research will focus on cMOOCs web based multimedia development and limited to basic mechanics subject.

Meanwhile, in research about cMOOCS And Global Learning: An Authentic Alternative (Carol Yeager, 2014) explained that cM00Cs can be used as a media to explore and to develop knowledge, skill, and individual behavior through provided contents and also can be used as place to build connection through discussion forum.

In a research study by Kristina (Kristina, 2014) concluded that students participation in cMOOCs based e-learning encouraged students to develop their selfabilities and improved their motivation. cM00Cs also demands students to be more active in their activities and collaborating with other participants in order to achieve their goals.

Observation results also showed that Open University in Indonesia has provided several certified online course materials in moocs.ut.ac.id. Those materials are the introduction to moodle 2.9, parenting, and marketing management. Basic mechanics has not been available in the following web. So the topic in this research choose mechanics subject.

The result of questionnaire through Google form which was given to 64 respondents from universities in Indonesia was $57.1 \%$ stated that their lecturers have already used online instructional media, while $52.45 \%$ have not yet. Those online instructional media were website which provide PDF file, while video or animation were not provided in those website. Discussion forum and certificate of graduation have not provided in those website either. However, there were exercise questions to evaluate students learning outcomes.

About $82,8 \%$ of respondents also stated that cMOOCs web has not already used as instructional media in their respective universities and $93.8 \%$ stated that the development of cMOOCs web based instructional media was necessary. Respondents were used to use gadget such as laptop or personal computer to access the information with the internet and 92.2\% agreed that the instructional media can encourage them to do a self-directed learning.

Based on argumentations above, this research is about Improving Students' Selfdirected Learning Outcomes on Mechanics Subject by Using E-Learning was done.

\section{Research Method}

Method used in this research was by Miles and Huberman action research with the following steps (Miles \& Huberman, 1994):

1) Data collection (secondary data, interview data, and event data)

2) Data presentation (pretest, mechanics subject learning using, e-learning and posttest)

3) Reduction / Exploration (collecting data based on research focus)

4) Verification / Member check: (analyzing focus to become more specific component) 


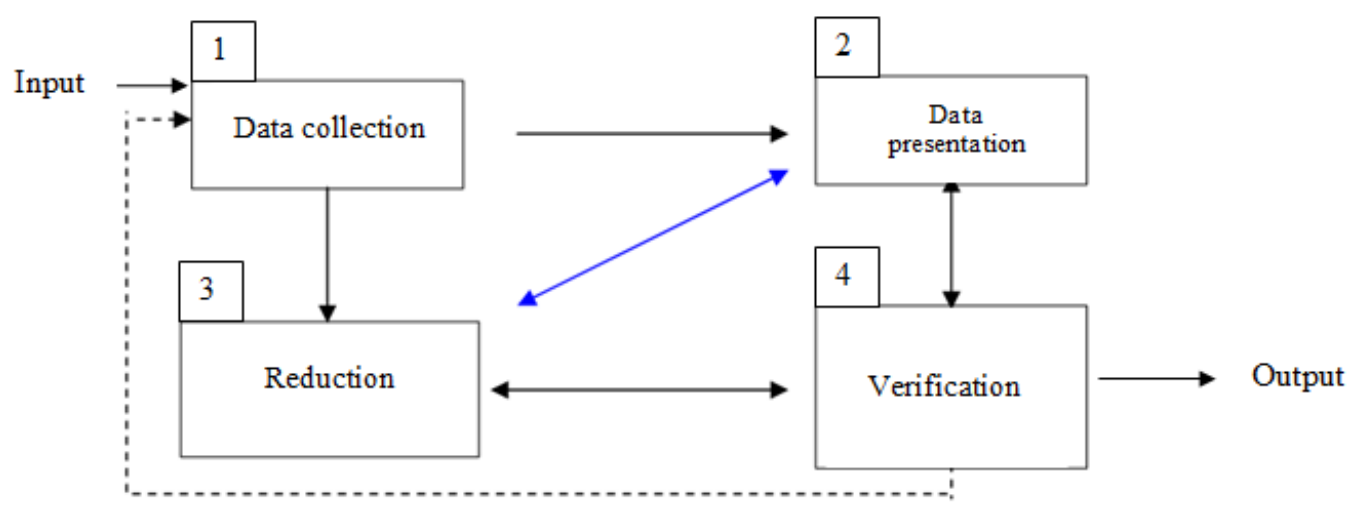

Fig. 1: Miles and Huberman's interactive analysis model

Instruments used in this research were mechanics multiple choice questions which consists of oscillation, mechanical wave, thermodynamics and students' selfdirected learning questionnaire. Questions were validated using point biserial formula and KR 20/21 to calculate its reliability (Widiyanto, 2014). Questions were used to find if there was an improvement of students' self-directed learning outcomes.
Questionnaire was used to rate students' initiative, self-efforts, and responsibility.

\section{Result and Discussion}

\section{Data collection}

Data collection was done by taking secondary data, interview data and event data as follows:

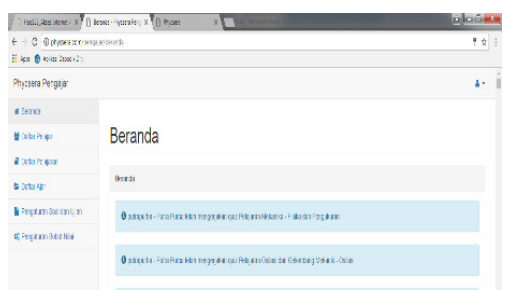

Fig. 2: Home of Web cMOOCs

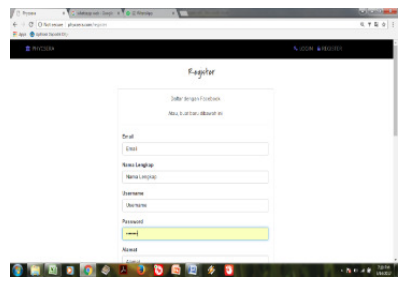

Fig. 3a: Register

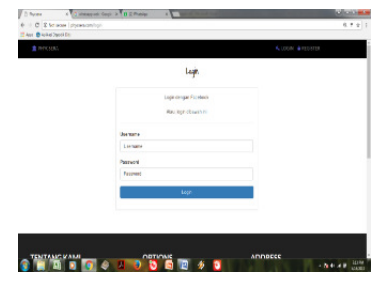

Fig. 3b: Login

Data presentation: Mechanics Subject

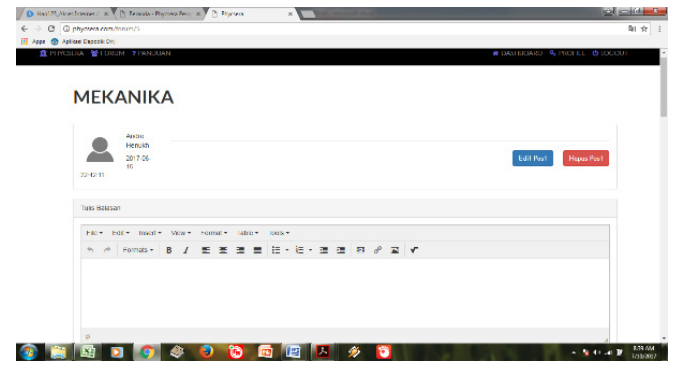

Fig. 4a: Mechanics Subject

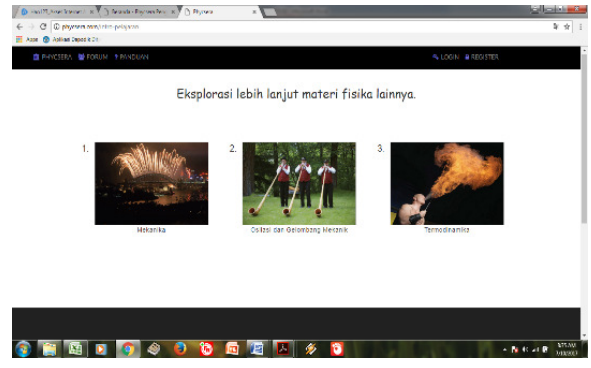

Fig. 4b:Mechanics Materials 


\section{Reduction of data}

Reduction of data was done by validating pretest and posttest questions. Validity and reliability test were done with results as follows:

a. Description of instruments' validity test.

Validation of self-learning outcomes instruments was done by using point biserial formula at significance level of $5 \%$ for 31 respondents, obtained $\mathrm{r}$ table $=$ 0.355. According to calculation, from 30 questions of mechanics subject only 20 questions considered valid; for oscillation and mechanical wave, from 20 questions, 14 questions were considered valid. Those valid questions were used as data collection instruments.

b. Description of instruments' reliability test.
Reliability test used KR-20/21 formula. The results of reliability test were: 0.91 for mechanics questions, 0.91 for oscillation and mechanical wave questions, and 0.95 for thermodynamics questions. Those results were interpreted as a very high category. According to Widiyanto, instruments were considered to have a high reliability if its reliability coefficient is between 0.8-1.0 (Widiyanto, 2014). At significance level of $5 \%$ for 31 respondents, r table was obtained by 0.355 (Sugiyono, 2015). According to calculation instruments used for data collection were valid and reliable.

\section{Verification}

Verification was done by analyzing pretest and posttest results. Data verification was done in two ways, by data triangulation and $\mathrm{N}$-gain test. $\mathrm{N}$-gain is the difference between posttest result and pretest result. $\mathrm{N}$-gain indicated students' improvements after learning is done (Hake, 1999).

$$
g=\frac{S_{\text {part }}-S_{\text {pre }}}{S_{\text {max }}-S_{\text {pre }}}
$$

$S_{\text {post }}$ is posttest score, $S_{\text {pre }}$ is pretest score and $S_{\max }$ is maximum score of test. $\mathrm{N}$-gain classifications are: (1) if $\mathrm{g} \geq 0,7, \mathrm{~N}$-gain is in high category; (2) if $0,7>\mathrm{g} \geq 0,3, \mathrm{~N}$-gain is in good category; and (3) if $\mathrm{g}<0,3 \mathrm{~N}$-gain is in low category. According to the calculation from 31 students who followed mechanics subject lecture, obtained $\mathrm{N}$-gain $=0.818$ and considered to be in high category.

Table 1: Test results

\begin{tabular}{|l|c|c|c|c|c|c|c|}
\hline \multirow{2}{*}{ No } & \multicolumn{3}{|c|}{ Test results } & \multirow{2}{*}{ No } & \multicolumn{3}{c|}{ Test results } \\
\cline { 2 - 3 } \cline { 7 - 7 } & Pretest & Posttest & Max Score & & Pretest & Posttest & Max Score \\
\hline 1 & 4 & 8 & 10 & 17 & 2 & 9 & 100 \\
\hline 2 & 4 & 9 & 10 & 18 & 3 & 8 & 100 \\
\hline 3 & 3 & 9 & 10 & 19 & 4 & 8 & 100 \\
\hline 4 & 4 & 8 & 10 & 20 & 3 & 9 & 100 \\
\hline 5 & 3 & 8 & 10 & 21 & 5 & 8 & 100 \\
\hline 6 & 3 & 8 & 10 & 22 & 4 & 9 & 100 \\
\hline 7 & 4 & 8 & 10 & 23 & 4 & 9 & 100 \\
\hline 8 & 2 & 8 & 10 & 24 & 3 & 8 & 100 \\
\hline 9 & 4 & 8 & 10 & 25 & 4 & 9 & 100 \\
\hline
\end{tabular}




\begin{tabular}{|l|l|l|l|l|l|l|l|}
\hline 10 & 3 & 9 & 10 & 26 & 3 & 7 & 100 \\
\hline 11 & 4 & 9 & 10 & 27 & 4 & 8 & 100 \\
\hline 12 & 2 & 9 & 10 & 28 & 1 & 9 & 100 \\
\hline 13 & 3 & 8 & 10 & 29 & 4 & 9 & 100 \\
\hline 14 & 2 & 9 & 10 & 30 & 3 & 8 & 100 \\
\hline 15 & 4 & 8 & 10 & 31 & 3 & 9 & 100 \\
\hline 16 & 4 & 8 & 10 & Tota & 1110 & 2739 & 3100 \\
\hline \multicolumn{7}{|c|}{ N-gain=0.818 } \\
\hline
\end{tabular}

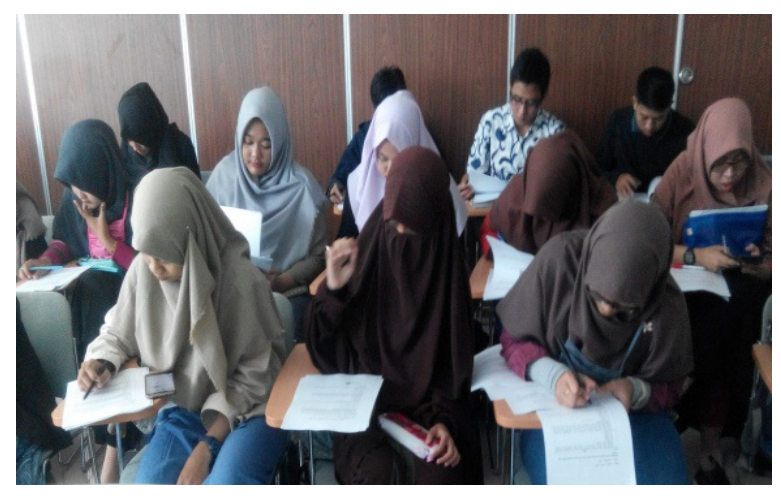

Fig. 5a: Pre-Test (before with E-Learning)
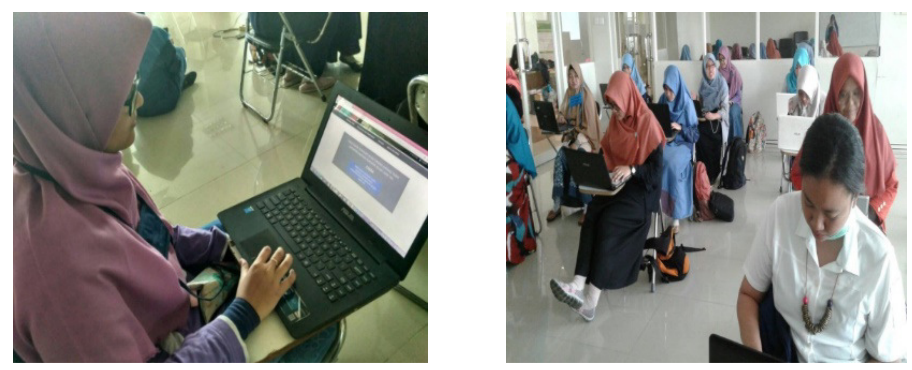

Fig. 5b. \& 5c. Post-Test (After with E-Learning)

Pretest and posttest result of students indicated that there was an improvement of students self-directed learning from Elearning usage.

Then, the questionnaire was also used to find students initiative, self-efforts and responsibility. Questionnaire referred to Likert scale interval. Likert scale is used to measure behavior, opinion, and perception about social issue or phenomena (Riduwan, 2007). Obtained data then interpreted as follows: 
Table 2: Likert scale (Sugiono, 2013)

\begin{tabular}{|c|c|}
\hline Average Score & Interpretation \\
\hline $0 \%-20 \%$ & Very Bad \\
\hline $21 \%-40 \%$ & Bad \\
\hline $41 \%-60 \%$ & Enough \\
\hline $61 \%-80 \%$ & Good \\
\hline $81 \%-100 \%$ & Very Good \\
\hline
\end{tabular}

The Questionnaire's result is shown in figure 6.

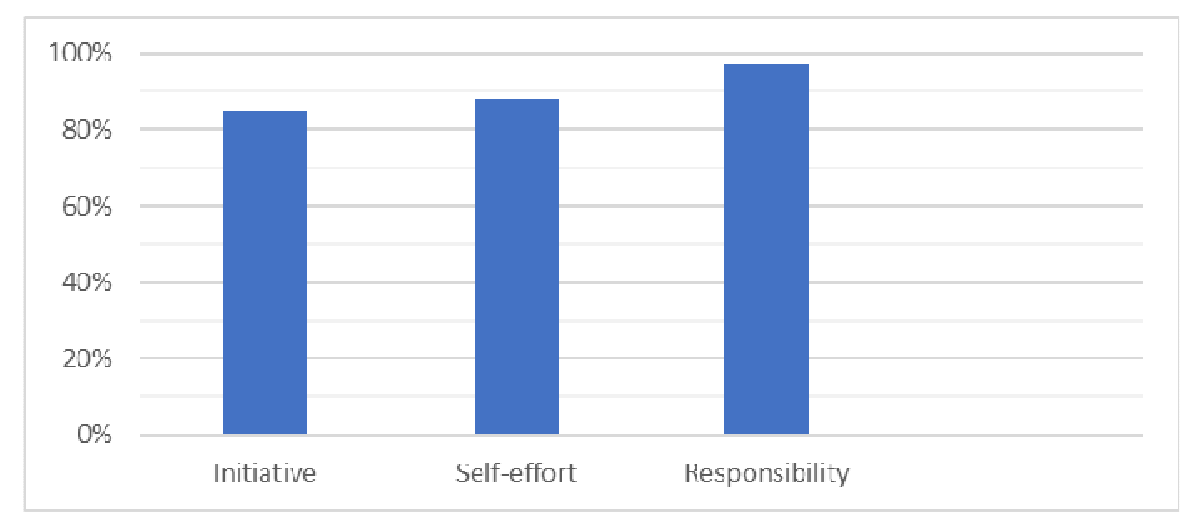

Fig. 6: Questionnaire result

According to graph above, the initiative aspects reached score $85 \%$, self-effort aspect $88 \%$ and responsibility $97 \%$. The results of the three aspects were in a very good category.

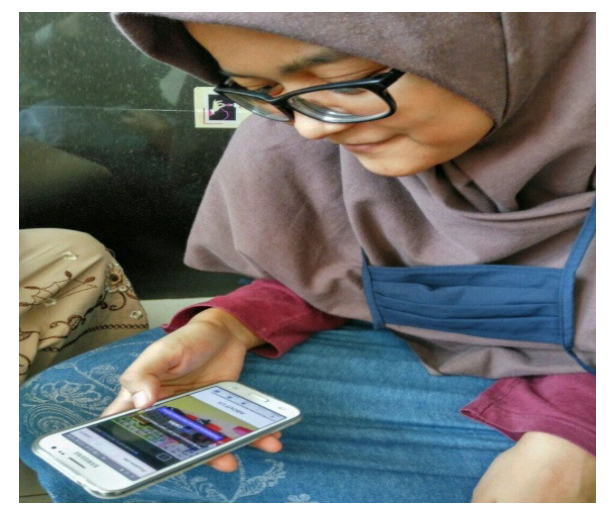

Fig. 7: Students answer questionnaire
Djoko (Djoko Rahardjo, 2016) concluded that with maximum effort in searching of information will help students to reach their learning goal. Then, the result of the aspects of initiative, self-effort and responsibility in this research is equal to previous research.

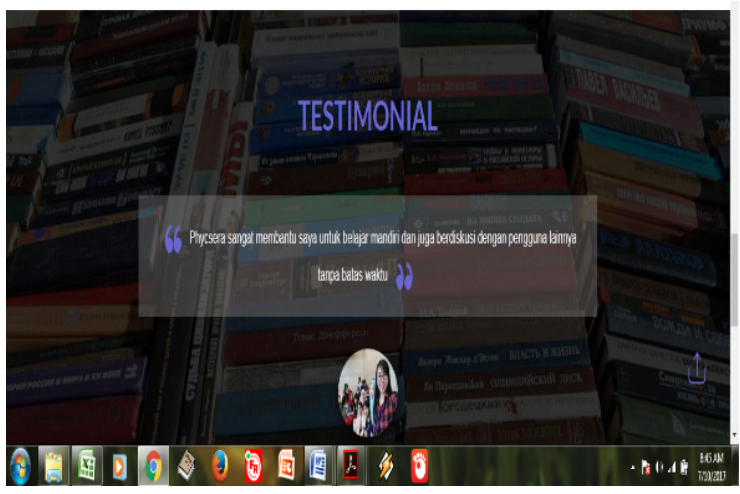

Fig. 8: Testimonia 


\section{Conclusion}

According to assesment result of elearning's effectivity, obtained $\mathrm{N}$-gain= 0,818 (high category). This result indicated the improvement of students' self-directed learning outcomes. Questionnaire showed students' initiative score by $85 \%$, self-effort by $88 \%$ and responsibility by $97 \%$. So, it can be concluded that there was an improvement of the students' self-directed learning outcomes in the mechanics subject using E-learning.

\section{References}

1. Antara News. (2016, May 3). IndonesiaX dan UNPAD luncurkan kursus online. Jakarta, DKI Jakarta, Indonesia.

2. Carol Yeager, B. H. (2014). cMOOCs and global learning: an authentic alternative. Journal of Asynchronous Learning Networks, 144-145.

3. Djoko Rahardjo, S. D. (2016). Internet Acces and Usage In Improving Students' Self-Directed Learning In Indonesian Open University. Turkish Online Journal of Distance Education, 38-39.

4. Hake, R. (1999). Analyzing change/gain scores. USA: Woodland Hills.

5. Kompas. (2012, November 27). Kembangkan TIK di dunia pendidikan. Jakarta, DKI Jakarta, Indonesia.
6. Kompas. (2014, January 7). E learning, agar pembelajaran makin luas. Jakarta, DKI Jakarta, Indonesia.

7. Kristina, M. \&. (2014). Participants' perceptions of learning and networking. MERLOT Journal of Online Learning and Teaching, 26.

8. Maha Bali, M. C. (2015). What makes a cMOOC community endure? Multiple participant perspectives from diverse cM00Cs. Educational Media International, 113.

9. Miles, M. B., \& Huberman, A. M. (1994). Qualitative data analysis: a sourcebook of new methods. Beverly Hills CA: Sage Publications.

10.Serevina, V. (2017). Development of enterpreneurship based learning model to increase physics learning outcomes of students. 29th International Business Information Management Association (pp. 122-129). Vienna: IBIMA.

11.Sugiono. (2013). Metode Penelitian Pendidikan: Pendekatan kuantitatif, kualitatif dan R\&D. Bandung: Alfabeta.

12. Sugiyono. (2015). Metode penelitian pendidikan. Bandung: Alfabeta.

13. Widiyanto, M. A. (2014). Statistika. Jakarta: Kalam Hidup. 